\title{
Acute effects of whole body vibration on foot sole sensitivity and plantar pressures during gait initiation
}

\author{
Martin Alfuth, Anne Beiring, Dieter Klein, Dieter Rosenbaum
}

From 3rd Congress of the International Foot and Ankle Biomechanics Community

Sydney, Australia. 11-13 April 2012

\section{Background}

Sensory receptors in the skin of the foot sole show a sitespecific sensitivity to local pressures and vibrations [1] and provide feedback during foot loading activities. Impaired plantar feedback has been shown to affect plantar pressures and kinematics during gait [2-5]. The present study investigated the acute effects of whole body vibration on plantar sensitivity and foot loading during gait.

\section{Materials and methods}

Fifteen healthy subjects $(28.4 \pm 4.4$ years $)$ were tested before and after 3 minutes of whole body vibrations at a frequency of $30 \mathrm{~Hz}$ (bilateral stance on a Galileo ${ }^{(B)}$ Med $M$ Plus vibration trainer with slightly bent knees). Semmes-Weinstein monofilaments were used to test plantar sensitivity to light touch at the hallux and the heel. Plantar pressures during gait initiation were recorded using an EMED-ST4 platform.

\section{Results}

Plantar sensitivity thresholds were significantly increased after whole body vibration $(\mathrm{p}<0.025)$, i.e. a decreased plantar sensitivity was observed under the heel $(5.8 \%)$ and the hallux (7.1\%; Fig. 1). No significant changes

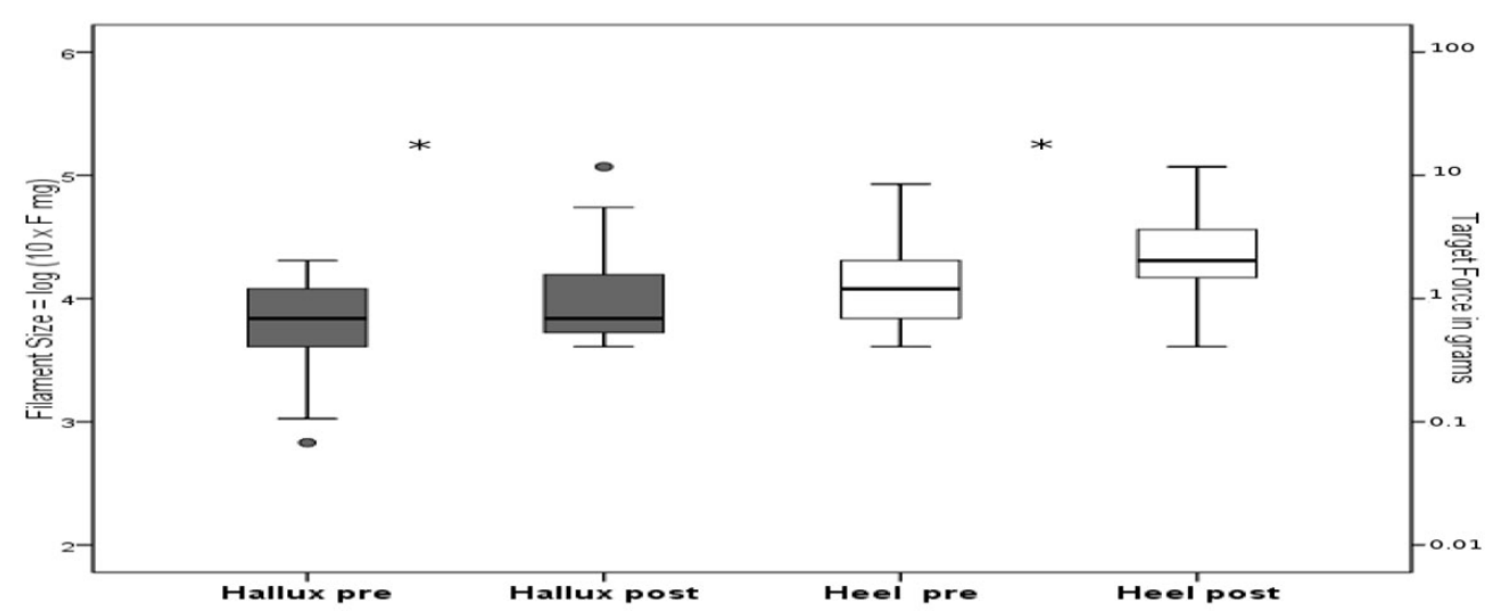

Figure 1 Boxplots with plantar sensitivity thresholds of the hallux and the heel before and after whole body vibration ( $\left.{ }^{*} p<0.025\right)$.

\footnotetext{
* Correspondence: diro@uni-muenster.de

Movement Analysis Laboratory, Institute of Experimental Musculoskeletal

Medicine (IEMM), University Hospital Muenster (UKM), Domagkstr. 3, 48149

Muenster, Germany
} 
were found in plantar pressure parameters during gait initiation.

\section{Conclusions}

In conclusion, high-intensity whole-body vibration affects plantar sensitivity by slightly increasing the sensory perception thresholds. However, this decrease in plantar feedback does not seem to be functionally relevant with respect to foot loading during gait initiation.

Published: 10 April 2012

\section{References}

1. Hennig EM, Sterzing T: Sensitivity mapping of the human foot. Foot Ankle Int 2009, 30:986-991.

2. Eils E, Behrens S, Mers O, Thorwesten L, Volker K, Rosenbaum D: Reduced plantar sensation causes a cautious walking pattern. Gait Posture 2004, 20:54-60.

3. Eils E, Nolte $S$, Tewes M, Thorwesten L, Volker K, Rosenbaum D: Modified pressure distribution patterns in walking following reduction of plantar sensation. J Biomech 2002, 35:1307-1313.

4. Nurse MA, Nigg BM: The effect of changes in foot sensation on plantar pressure and muscle activity. Clin Biomech (Bristol, Avon) 2001, 16:719-727.

5. Nurse MA, Nigg BM: Quantifying a relationship between tactile and vibration sensitivity of the human foot with plantar pressure distributions during gait. Clin Biomech (Bristol, Avon) 1999, 14:667-672.

doi:10.1186/1757-1146-5-S1-024

Cite this article as: Alfuth et al:: Acute effects of whole body vibration on foot sole sensitivity and plantar pressures during gait initiation. Journal of Foot and Ankle Research 2012 5(Suppl 1):O24.

\section{Submit your next manuscript to BioMed Central} and take full advantage of:

- Convenient online submission

- Thorough peer review

- No space constraints or color figure charges

- Immediate publication on acceptance

- Inclusion in PubMed, CAS, Scopus and Google Scholar

- Research which is freely available for redistribution

Submit your manuscript at www.biomedcentral.com/submit 